\title{
Hydrothermal bowls in the giant Cretaceous Botucatu paleoerg
}

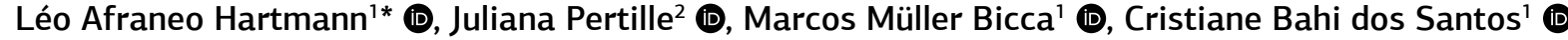

\begin{abstract}
Fascinating circular hydrothermal bowls $0.5 \mathrm{~m}$ in diameter occur in paleodunes of the 1.2 million $\mathrm{km}^{2}$ Botucatu paleoerg in the Fronteira Oeste of Brazil, Rio Grande do Sul, and were exposed upon erosion of presumed 2,000 m of basalt and rhyodacite cover of the Paraná Volcanic Province $\left(1\right.$ million $\left.\mathrm{km}^{2}\right)$ since the Cretaceous $(135 \mathrm{Ma})$. The tops of the paleodunes display low-temperature $\left(150-50^{\circ} \mathrm{C}\right)$ hydrothermal structures comparable to those in basalts and rhyodacites. The source beds of sand injectites display evidence of sequential fault-valve action. The bowls represent a new structure in continental paleodunes. They present circular rims sealed by quartz and a flat horizontal bottom with a central sealed vent. The inclined internal rims of the bowls exhibit a radial set of linear fractures filled with quartz, forming prominent, sharp, positive structures. Their origin is ascribed to the work of water vapor originated in the heated freshwater aquifer. The concave ceiling was lifted a few millimeters along circular fractures long enough for quartz to be deposited. Erosional exhumation of the buried Botucatu hyperdry sand sea has revealed the effects, including the new structures described here, of hydrothermalism associated with a major igneous province upon a giant paleoerg turned-aquifer.
\end{abstract}

KEYWORDS: hydrothermal bowl; paleodune; Botucatu paleoerg; Paraná Volcanic Province; Guarani Aquifer.

\section{INTRODUCTION}

The interplay of several processes resulted in the formation of a large variety of structures at the interface of heated freshwater $\left(150^{\circ} \mathrm{C}\right)$ from the Guarani Aquifer with the host Botucatu paleoerg $\left(1.2\right.$ million $\left.\mathrm{km}^{2}\right)$ and the overlying Paraná Volcanic Province $\left(1.0\right.$ million $\left.\mathrm{km}^{2}\right)$. The basalts and rhyodacites formed a large igneous province in Gondwana, extending from southeastern South America (Brazil, Uruguay, Argentina, Paraguay) to western Africa (Namibia, Congo, Angola).The heating of the underlying aquifer resulted in sand injection into many lava flows of the province culminating in effusion on top of flows in a continued hyperdry desert (Botucatu desert - Amarante et al.2019, Serra Geral desert - Hartmann and Cerva-Alves 2021). In this paper we examine the bowls discovered at the top of the paleodunes present amid the effusive Catalán andesite (Hartmann et al. 2010). Dunes were formed between 150-135 Ma (Hartmann et al. 2019, Hartmann and Cerva-Alves 2021). Intense hydrothermal injection and effusion of loose sand and silt from the erg occurred throughout the basalt province (Hartmann et al. 2012a, 2012b).

The bowls occur in paleodunes of the Botucatu Formation (Scherer 2000, Bertolini et al. 2020) from the Cretaceous

\footnotetext{
${ }^{1}$ Instituto de Geociências, Universidade Federal do Rio Grande do Sul - Porto Alegre (RS), Brazil. E-mails: leo.hartmann@ufrgs.br, marcos. mb83@gmail.com, cristianebahi@gmail.com

${ }^{2}$ Centro de Desenvolvimento Tecnológico, Universidade Federal de Pelotas - Pelotas (RS), Brazil. E-mail: juliana.pertill@gmail.com ${ }^{*}$ Corresponding author.
}

(150-135 Ma; Hartmann and Cerva-Alves 2021), formed in a continental environment. The circular structures were exposed after the erosion of presumed 2,000 $\mathrm{m}$ of basalt and rhyodacite cover since the Cretaceous (135 Ma). Field work allowed characterization of the bowls as a result of water vapor venting through silicified sandstone, likely below $0.5 \mathrm{~m}$ of andesite and some sandstone.

\section{MATERIAL AND METHODS}

Regional geological surveys of the studied region (Silva et al.2004) and its extension to the east (Bergmann et al. 2020) were revised, as well as the pioneering work of Hartmann and Cerva-Alves (2021) on the description of the Fronteira Oeste region. Satellite images yielded basic information regarding the distribution of paleodune tops and flooding basaltic rocks. The Santa Helena paleodune was selected for field observations. The authors described rocks and structures; hydrothermal bowls are currently reported. The bowls were not hammered for the sake of preservation of this first find in a major paleoerg covered by a major basalt province.

\section{RESULTS}

The bowls were found (coordinates 2941'47" S; 55 59'55" W) in the silicified and fractured Santa Helena paleodune in the Fronteira Oeste region (Hartmann and Cerva-Alves 2021) of southernmost Brazil (Figs. 1 and 2A). The $150 \times 100 \mathrm{~km}$ studied region is flat-lying due to its $\mathrm{NW}$-aligned arching of the continental crust across 50-100 km (Rio Grande arch), positioning the sedimentary and volcanic rocks nearly horizontal. As a 


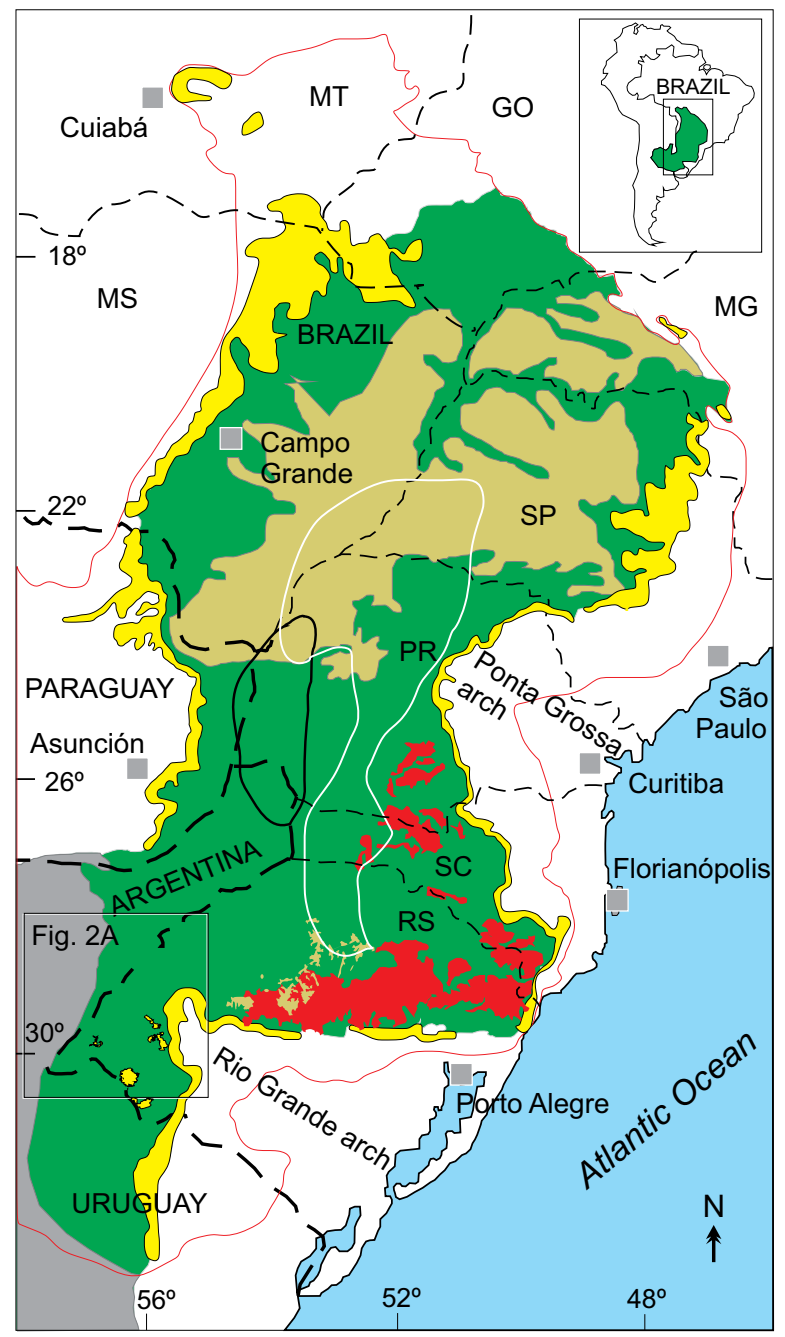

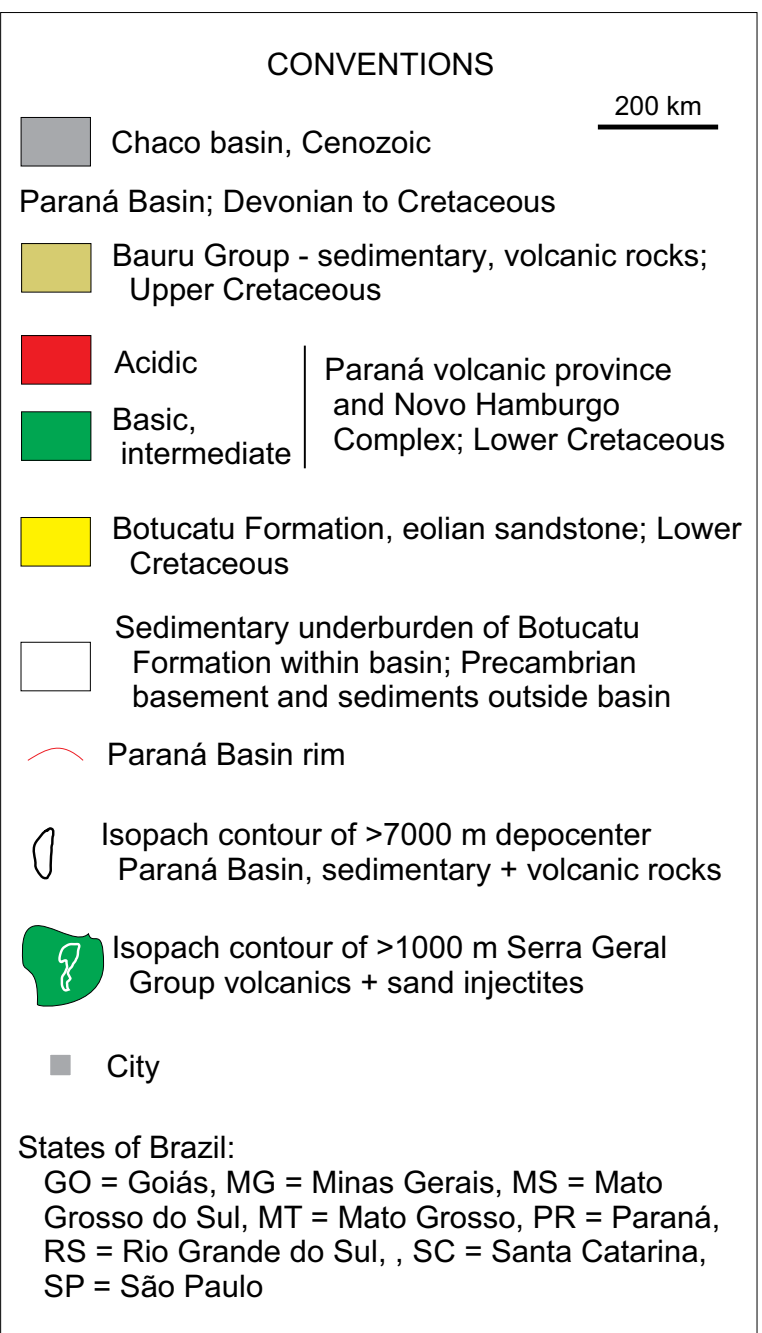

Figure 1. Geological map of Serra Geral Group (Hartmann and Cerva-Alves 2021), indicating location of Fronteira Oeste region.
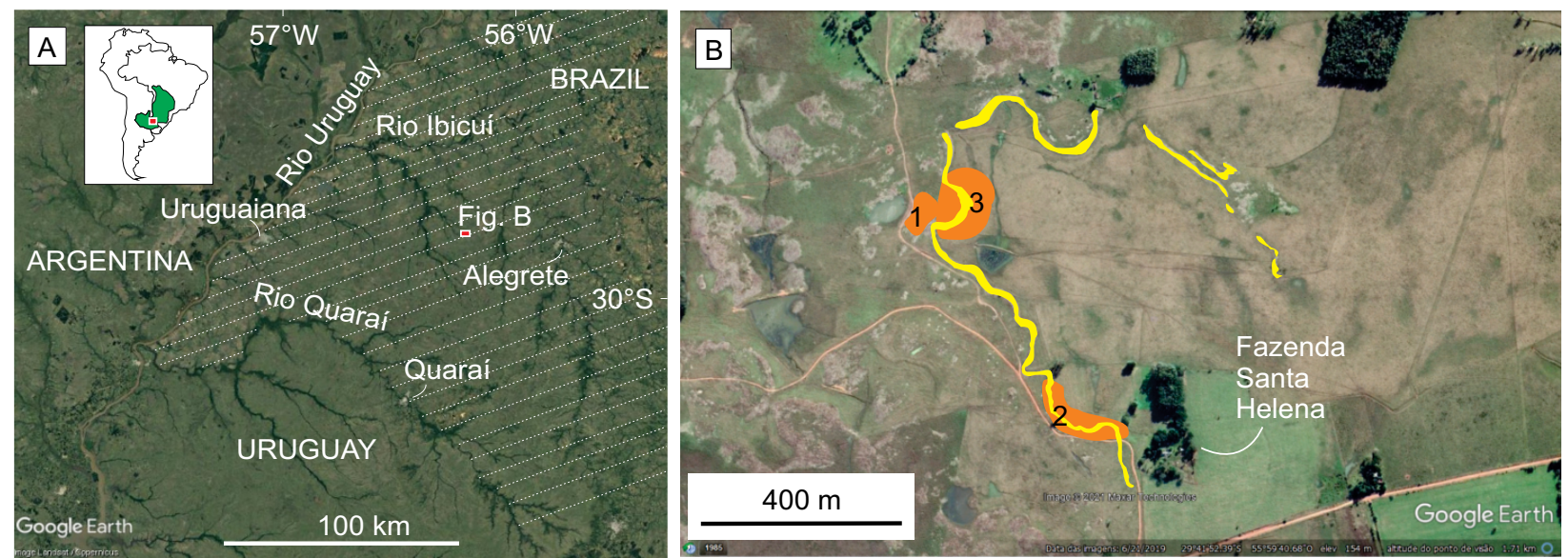

Figure 2. (A) Fronteira Oeste as a geographic subdivision of Brazil in Rio Grande do Sul state, marked with inclined white lines. This region is underlain by fault-block structures. Towns and rivers marked. Inset displays location of study area in the Paraná Volcanic Province in South America. Studied area indicated as Fig. 2B. (B) Studied Santa Helena compound paleodune drawn in yellow, displaying barchan and seif sand mounds; studied locations 1, 2, 3 indicated.

consequence, the first lava flow (Catalán andesite) is exposed at the contact with the top of the paleodunes (Hartmann and Cerva-Alves 2021).

Several bowls occur in the studied paleodune, but most are poorly structured, leading us to focus on the main, complete bowl (Fig. 2B) in the Santa Helena paleodune. Bowls are outstanding structures in the paleodunes (Figs. 3 and 4). Bowl 1 is $50 \times 40 \mathrm{~cm}$ across, $15 \mathrm{~cm}$ deep, developed on a substrate of silicified, fine to medium sandstone. The Botucatu Formation has (Bertolini et al. 2020) abundant quartz (89\%), some 

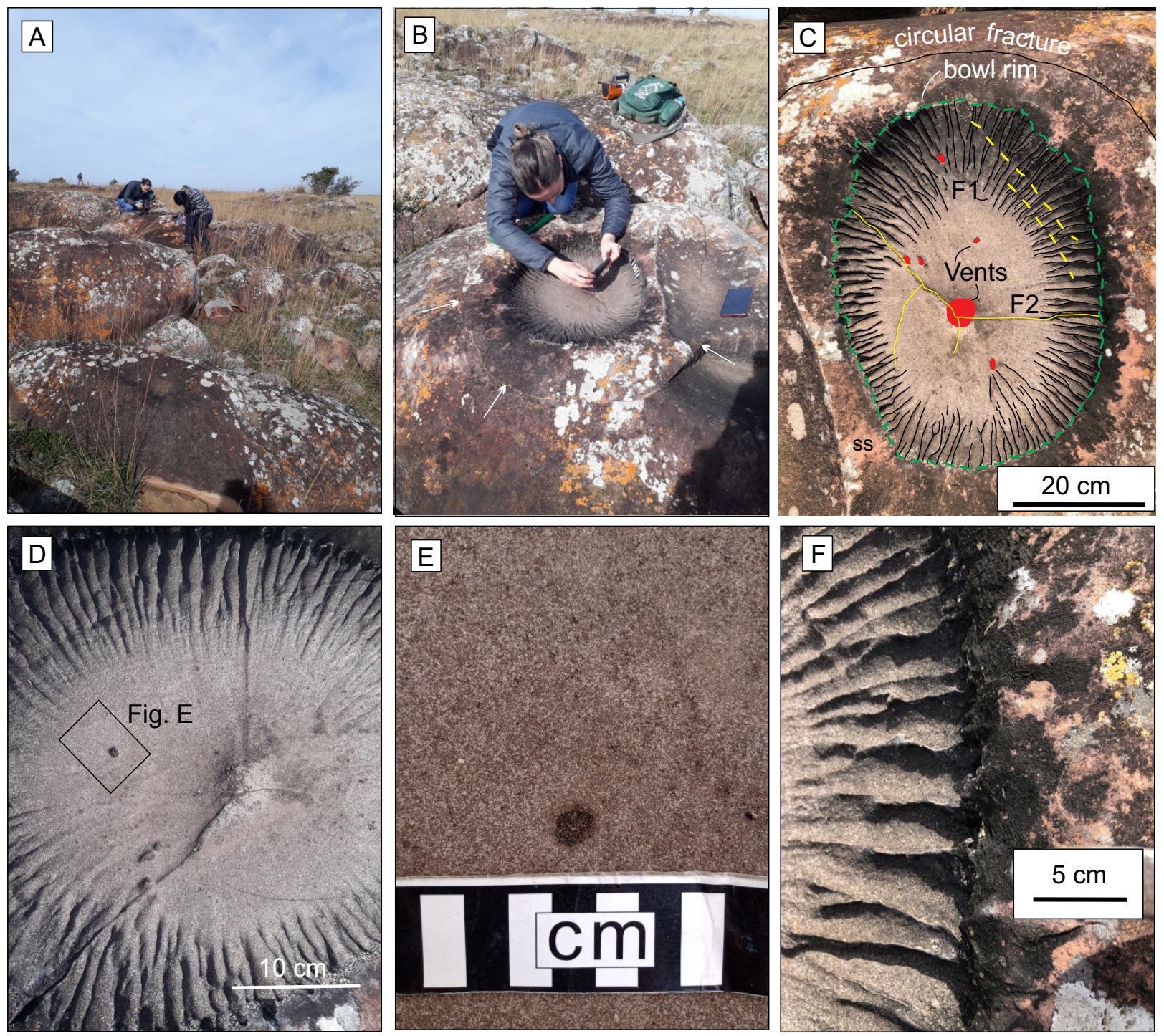

Figure 3. Field photos of paleodune Santa Helena, location 1. (A) View looking east to outcrop with bowls; (B) Bowl 1, showing circling, silicified fracture (white arrows), internal salient, radial fractures filled with quartz; white lichen on sandstone, dark lichen fragments with many oxide grains and calcite circling the bowl; (C) Drawing of bowl 1, displaying central and minor filled vents (red), radial fractures F1 filled with quartz screens (black), and fractures F2 crossing the bowl (yellow); bowl rim is defined by the ending of F1 fractures; external circular fracture shown (black); ss = fresh red, silicified sandstone exposed by scaling-off of dark lichen fragments and mineral grains; (D) Close-up view of bowl 1, showing position of Fig. E; (E) Vent (dark) inside bowl 1; cross-section of vent is hexagonal; (F) Rim of bowl 1, showing quartz-filled fractures reaching the supporting silicified sandstone. Black fringe outside rim are dead lichen.

feldspar (8\%) and lithic fragments (3\%); mafic minerals present in small amounts are zircon, tourmaline and rutile (mean ZTR $=0.84$ ) with sporadic garnet and epidote. The bowl has a remarkable aspect and structure, particularly radiating fractures (F1), each containing a knife-sharp quartz sheet in the middle. The flat bottom of the bowl is homogeneous except for a central, sealed vent and several smaller sealed vents, as well as a marked fracture that crosses the bowl (F2) from rim to rim and across the sealed central vent. A circular fracture embraces the bowl at a horizontal distance of $10-15 \mathrm{~cm}$ from the rim.

Other bowls occur in the outcrop (Fig. 4), all in the topmost position of rounded sandstone remnants. Erosion of the sandstone resulted in the preservation of silicified portions, preserving the bowls at the top due to the highest intensity of silicification.

\section{DISCUSSION}

In order to form the bowls, we envisage a sequence of hydrothermal processes resulting from the heating of the Guarani Aquifer by a raised geothermal gradient and sill cooling. Heat was released from the upper mantle to warm up the aquifer and the crust $\left(150^{\circ} \mathrm{C}\right)$ during the generation of the Paraná Volcanic Province. As observed regionally in the rift and the province, a sequence of hydrothermal events occurred. The first $\mathrm{H} 1$ event sealed the basalts, followed by explosive injection and effusion (H2) of sand and silt (Duarte et al. 2020, Hartmann and Duarte 2020). After lava cooling to room temperature, a basaltic lava is porous $(30 \%)$, requiring a geological process to seal the porosity for further hydrothermal evolution. The initial percolation of hot water and its vapor (H1) through the basalt leads to sealing (S1). As a consequence, the rock will sustain pressure from the heated aquifer until rupture of the 

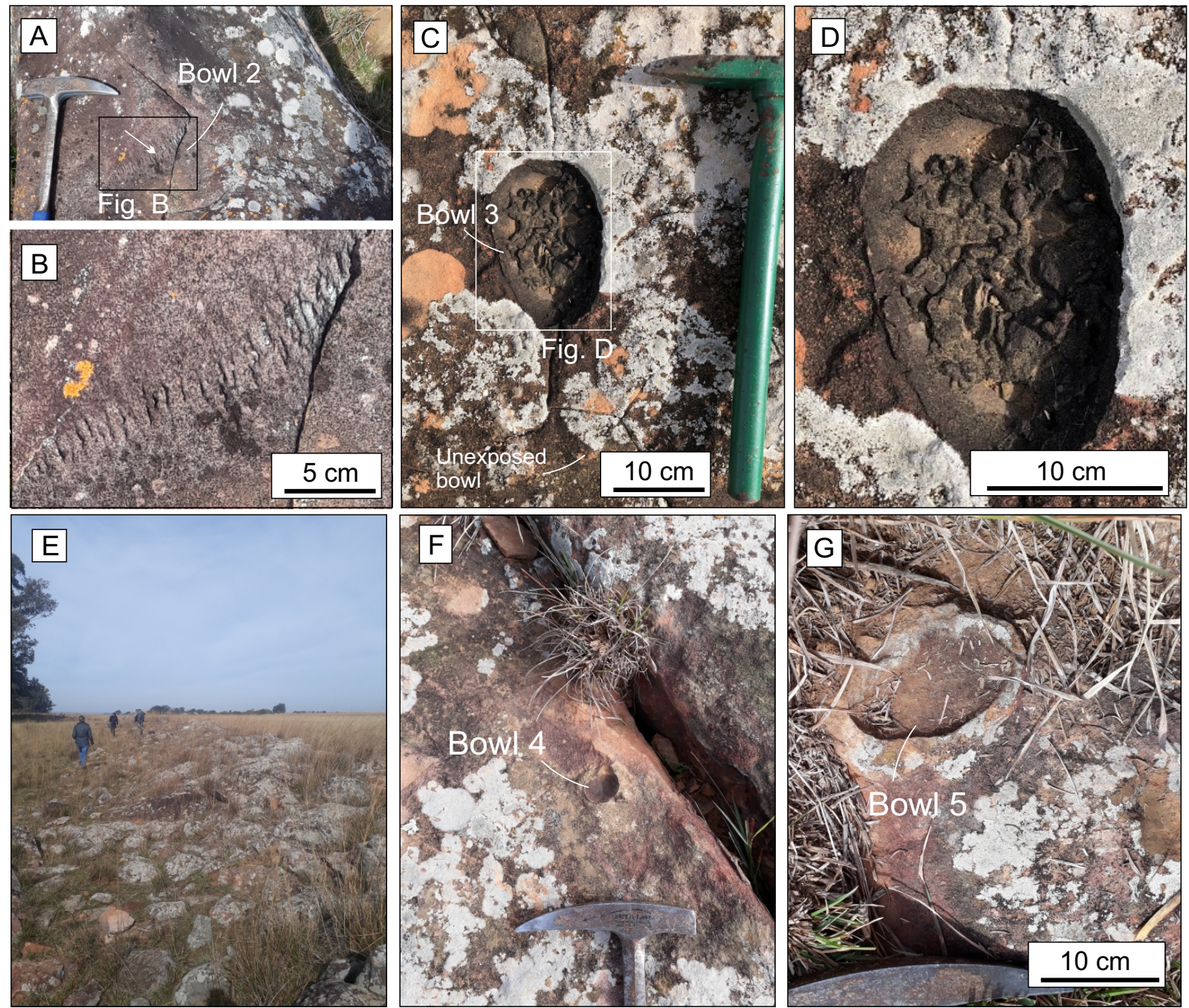

Figure 4. Field photos of paleodune Santa Helena, locations (A, B, C and D) 1 and (E, F and G) 2; (A) Bowl 2, displaying aligned quartz-filled fractures in (B); (C) bowl 3, and an unexposed bowl with three fractures; amoeboid fractures filled with silicified sandstone detailed in (D); (E) Field photo of location B, showing paleodune; (F) small bowl 4; (G) unexposed bowl 5.

seal and sand injection (H2). Renewed sealing of the basalts led to slow percolation (H3) of water vapor, the alteration of the basalt and formation of amethyst geodes (Duarte et al. 2009).

We currently interpret similar processes in the underlying sandstones, whereby the sealed sandstone $(\mathrm{H} 2)$ was breached by ascending vapor $(\mathrm{H} 3)$. As the force exerted by the vapor became equal to the weight of the overlying sand + basalt, the base of the bowl was fractured radially. Radial fractures were filled with hydrothermal quartz and the top of the bowls was lifted along a circular fracture. Vapor pressure kept the silicified sandstone upper disc lifted until the vents were clogged with hydrothermal minerals. After sealing, continued vapor pressure resulted in renewed fracturing across the bowls.

Hydrothermal processes were overall comparable to the Yellowstone caldera (Kharaka et al. 2000, Morgan et al. 2009, Tan et al. 2020). In the Paraná Basin, siliceous hydrothermal cones $\left(200-150^{\circ} \mathrm{C}\right)$ are encased in dolomites from the Permian Teresina Formation (Amaral 2016).

Regional control of bowl occurrence was caused by the rifting of the continental crust of the region, related to the formation of the South Atlantic Ocean (Hartmann and Cerva-Alves 2021). This rifting extends along the coast to the north and south of the studied region. The rift also expands to the west into Argentina, where it merges with the back-arc fracturing of the Andes.

The discovery and field characterization of hydrothermal bowls in paleodunes of a large paleoerg, covered in the Cretaceous by a major continental basaltic province adds to the geological understanding of processes in the continents. The presence of an active paleoerg covered by basaltic lavas from a large continental volcanic province resulted in a record of hydrothermal processes which are unique in the continents. The understanding of these processes may lead to clarification of geological relationships in other continental provinces that display similar features to the ones described here.

\section{ACKNOWLEDGEMENTS}

We acknowledge the support from Conselho Nacional do Desenvolvimento Científico e Tecnológico (CNPq), Government of Brazil, for a grant linked to a research scholarship to Léo A. Hartmann. We are thankful to Guilherme Gazapina Schmidt and Kátia Lagreca Schmidt from Estância Santa Rita do Jarau for their hospitality (during the pandemic). Two journal reviewers made significant contributions to the improvement of the article. 


\section{ARTICLE INFORMATION}

Manuscript ID: 20210058. Received on: 07/19/2021. Approved on: 11/15/2021.

L.H. did field work, wrote the first draft of the manuscript and prepared the figures; J.P. and M.B. did field work, improved the manuscript through corrections and suggestions; C.S. did field work.

Competing interests: The authors declare no competing interests.

\section{REFERENCES}

Amaral M. 2016. Reinterpretação dos domos de Anhembi, SP: evidência de exsudação de metano durante o Permiano da Bacia do Paraná. Senior undergraduate thesis, Instituto de Geociências e Ciências Exatas, Universidade Estadual Paulista “Júlio de Mesquita Filho”, 34 p.

Amarante F.B., Scherer C.M.S., Aguilar C.A.G., Reis A.D., Mesa V., Soto M. 2019. Fluvial-eolian deposits of the Tacuarembó formation (Norte Basin-Uruguay): Depositional models and stratigraphic succession. Journal of South American Earth Sciences, 90:355-376. https://doi.org/10.1016/j.jsames.2018.12.024

Bergmann M., Rocha P.G., Sander A., Parisi G.N. (Eds.) 2020. Modelo prospectivo para ametista e ágata na fronteira sudoeste do Rio Grande do Sul. Avaliação de Recursos Minerais do Brasil. Áreas de Relevante Interesse Mineral - ARIM. CPRM, 129 p. Available from: http://rigeo.cprm.gov.br/ jspui/handle/doc/18795. Accessed on: Dec 4, 2020.

Bertolini G., Marques J.C., Hartley A.J., Da-Rosa A.A.S., Scherer C.M.S., Basei M.A.S., Frantz J.C. 2020. Controls on Early Cretaceous desert sediment provenance in south-west Gondwana, Botucatu Formation (Brazil and Uruguay).Sedimentology, 67(5):2672-90.https://doi.org/10.1111/sed.12715

Duarte L.C., Hartmann L.A., Vasconcellos M.A.Z., Medeiros J.T.N., Theye T. 2009. Epigenetic formation of amethyst-bearing geodes from Los Catalanes gemological district, Artigas, Uruguay, southern Paraná Magmatic Province. Journal of Volcanology and Geothermal Research, 184(3-4):427-436. https:// doi.org/10.1016/j.jvolgeores.2009.05.019

Duarte S.K., Hartmann L.A., Baggio S.B. 2020. Fluidized sand effusion over successive basalt flows of the northwestern Paraná volcanic province. Journal of South American Earth Sciences, 99:102505. https://doi.org/10.1016/j. jsames.2020.102505

Hartmann L.A., Arena K.R., Duarte S.K. 2012a. Geological relationships of basalts, andesites and sand injectites at the base of the Paraná volcanic province, Torres, Brazil. Journal of Volcanology and Geothermal Research, 237-238:97-111. https://doi.org/10.1016/j.jvolgeores.2012.05.017

Hartmann L.A., Baggio S.B., Brückmann M.P., Knijnik D.B., Lana C., Massonne H.J., Opitz J., Pinto V.M., Sato K., Tassinari C.C.G., Arena K.R. 2019. U-Pb geochronology of Paraná volcanics combined with trace element geochemistry of the zircon crystals and zircon Hf isotope data. Journal of South American Earth Sciences, 89:219-226. https://doi.org/10.1016/j.jsames.2018.11.026

Hartmann L.A., Cerva-Alves T. 2021. Resurfaced paleodunes from the Botucatu erg amid Cretaceous Paraná volcanics. Geomorphology, 383:107702. https://doi.org/10.1016/j.geomorph.2021.107702
Hartmann L.A., Duarte L.C., Massonne H.J., Michelin C., Rosenstengel L.M., Bergmann M., Theye T., Pertille J., Arena K.R., Duarte S.K., Pinto V.M., Barboza E.G., Rosa M.L.C.C., Wildner, W. 2012b. Sequential opening and filling of cavities forming vesicles, amygdales and giant amethyst geodes in lavas from the southern Paraná volcanic province, Brazil and Uruguay. International Geology Review, 54(1):1-14. https://doi.org/10.1080/00206 814.2010 .496253

Hartmann L.A., Duarte S.K. 2020. Novo Hamburgo Complex formed by hydrothermal, explosive injection of Botucatu erg sand into extensive tracts of Paraná volcanic province. Journal of Sedimentary Environments, 5:187-198. https://doi.org/10.1007/s43217-020-00015-6

Hartmann L.A., Wildner W., Duarte L.C., Duarte S.K., Pertille J., Arena K.R., Martins L.C., Dias N.L. 2010. Geochemical and scintillometric characterization and correlation of amethyst geode-bearing Paraná lavas from the Quaraí and Los Catalanes districts, Brazil and Uruguay. Geological Magazine, 147(6):954-970. https://doi.org/10.1017/ S0016756810000592

Kharaka Y.K., Sorey M.L., Thordsen, J.J. 2000. Large-scale hydrothermal fluid discharges in the Norris-Mammoth corridor, Yellowstone National Park, USA. Journal of Geochemical Exploration, 69-70:201-205. https://doi. org/10.1016/S0375-6742(00)00025-X

Morgan L.A., Shanks III W.C.P., Pierce K.L. 2009. Hydrothermal processes above the Yellowstone magma chamber: Large hydrothermal systems and large hydrothermal explosions. Geological Society of America, Special Paper, 459. https://doi.org/10.1130/2009.2459(01)

Scherer C.M.S. 2000. Eolian dunes of the Botucatu Formation (Cretaceous) in southernmost Brazil: morphology and origin. Sedimentary Research, 137(1-2):63-84. https://doi.org/10.1016/S0037-0738(00)00135-4

Silva M.A.S., Favilla C.A.C., Wildner W., Ramgrab G.E., Lopes R.C., Sachs L.L.B., Silva V.A., Batista I.H. 2004. Folha SH.21-Uruguaiana. In: Schobbenhaus C., Gonçalves J.H., Santos J.O.S., Abram M.B., Leão Neto R., Matos G.M.M., Vidotti R.M, Ramos M.A.B., Jesus J.D.A. de. (Eds.). Carta Geológica do Brasil ao Milionésimo. Sistema de Informações Geográficas. Programa Geologia do Brasil. Brasília: CPRM. CD-ROM.

Tan C., Fowler A., Tutor A., Seyfried Jr. W.E. 2020. Heat and mass transport in sublacustrine vents in Yellowstone Lake, Wyoming: In-situ chemica and temperature data documenting a dynamic hydrothermal system. Journal of Volcanology and Geothermal Research, 405:107043. https://doi. org/10.1016/j.jvolgeores.2020.107043 